\title{
Synthesis and screening of 2,6-diamino-substituted purine derivatives as potential cardiomyogenesis inducing agents
}

\author{
Moumita Koley, ${ }^{\mathrm{a}}$ Xaver König, ${ }^{\mathrm{b}}$ Karlheinz Hilber, ${ }^{\mathrm{b}}$ Michael Schnürch, ${ }^{\mathrm{a}^{*}}$ Peter Stanetty, \\ and Marko D. Mihovilovic ${ }^{\mathrm{a}}$ \\ ${ }^{a}$ Institute of Applied Synthetic Chemistry, Vienna University of Technology, \\ Getreidemarkt 9/163-OC, 1060 Vienna, Austria \\ ${ }^{b}$ Center of Physiology and Pharmacology, Institute of Pharmacology, Medical University \\ of Vienna, Waehringerstraße 13, A-1090 Vienna, Austria \\ E-mail: mschnuerch@ioc.tuwien.ac.at
}

Dedicated to Prof. Heinz Heimgartner on the occasion of his $70^{\text {th }}$ birthday

\begin{abstract}
The synthesis of 2,6-diamino-substituted purines is reported starting from 2,6-dichloropurine via two subsequent selective nucleophilic substitution reactions. The first substitution takes place selectively in 6-, the second in 2-position. The compounds were synthesized as structural analogs of reversine, a substance which was reported to possess the ability to de-differentiate lineagecommitted cells into progenitor cells which then can be differentiated into other cell types such as adipocytes or osteoblasts. The obtained compounds were tested regarding their potential to support cardiomyogenic cell differentiation based on preliminary findings that reversine also showed some activity in this regard.
\end{abstract}

Keywords: Aminopurines, nucleophilic substitution, reversine, cardiogenol

\section{Introduction}

Purines and aminopurines are important compound classes with various physiological and pharmacological properties. ${ }^{1}$ For example, purine derivatives are reported to act as nucleotide binding proteins that play a significant role in many biological processes. ${ }^{2}$ Other representatives of this class have antirhinovirus ${ }^{3}$ or antitumor activity as kinase inhibitors. ${ }^{4}$ Consequently, a large number of purine libraries have been synthesized in solution ${ }^{5}$ or using solid polymer supports. ${ }^{6}$

Recently, reversine - a 2,6-diamino-substituted purine (Figure 1) - was reported to induce myogenic lineage-committed cells ( $\mathrm{C} 2 \mathrm{C} 12$ skeletal myoblasts) to become multipotent progenitor 
cells which can proliferate and re-differentiate into osteoblasts and adipocytes. ${ }^{7}$ This is a very interesting finding since influencing cell differentiation processes is an extremely active research topic at present offering the prospect of regenerative medical intervention. The methods to influence differentiation processes are diverse. For example, lineage conversions can be induced through the introduction of certain transcription factors representing a genetic intervention, also referred to as gene therapy. ${ }^{8}$ Additionally, it was demonstrated that the transfer of nuclei from either embryonic or somatic cell types can lead to the formation of all three germ layers and, most remarkably, even to the generation of entire new animals. ${ }^{9}$ A recent development which stirred much attention was the reprogramming of somatic cells to induced pluripotent stem cells (iPSCs) by the overexpression of a transcription factor cocktail. ${ }^{10}$ These extremely remarkable results have certain flaws: a retrovirus is required to insert genes into the genome in order to induce the de-differentiation process into a progenitor cell. As a consequence, there is an unacceptable risk of permanent transgene integration into the genome. Additionally, two of the used reprogramming factors (Klf4 and c-Myc) in the original publication are oncogenic. However, this issue was already addressed by several research groups and methods which avoid these two genes have been published. ${ }^{10 f, 11}$ Still, both facts make the approval of such a method for medicinal applications quite unlikely. Besides the aforementioned problems, iPSC reprogramming is still a slow and inefficient process.

The usage of synthetic small molecules (SySMs) in therapies involving cell differentiation processes would be highly desirable, since most approved drugs are based on the application of such compounds, and methods to test for activity and toxicology are well established. This suggests that processes leading to approval of these compounds for treatment in patients will be more facile compared to other methods such as inserting genes into the cells via a retrovirus. Up to date, only a handful of SySMs influencing cell differentiation have been reported. ${ }^{12}$ For example, neurodazine ${ }^{13}$ and neuropathiazole ${ }^{14}$ were reported as agents able to initiate a transformation of certain cell types towards neurons. Cardiogenol $\mathrm{C}^{15}$ and Shz $1^{16}$ induce the transformation of stem cells towards cardiomyocytes. This is a very interesting feature since, compared to other tissues, the heart usually displays a very limited regenerative capacity after injury. ${ }^{17}$ Therapies based on the application of such chemicals have the potential to become highly important in the treatment of neurodegenerative diseases or in the treatment of patients after a myocardial infarction.

Based on preceding publications, reversine and cardiogenol $\mathrm{C}$ served as inspiration and lead structures for the current project. As can be seen from Figure 1, the two molecules have structurally large similarities (marked in blue). Since cardiogenol C exerts a strong cardiomyogenic effect on embryonic stem cells, ${ }^{15}$ a similar activity of reversine and derivatives thereof should be tested. In this regard, a convenient and fast synthetic method for the preparation of a library of these compounds was required. Within this contribution, a facile synthetic route as well as initial biological results are reported. 


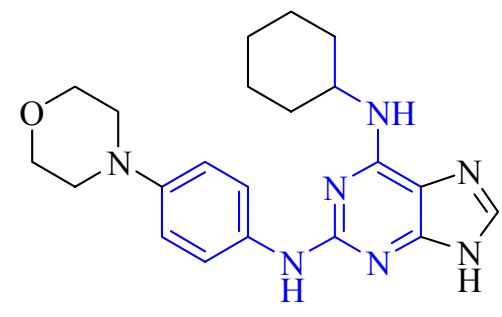

Reversine

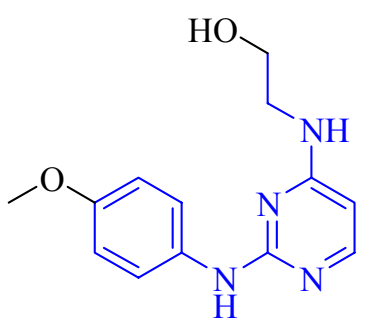

Cardiogenol C

Figure 1. Structural similarities between reversine and cardiogenol C.

\section{Results and Discussion}

The synthesis of reversine has been reported in the literature starting from 2-fluoro-6-chloro-9Hpurine as the starting material with $67 \%$ overall yield. ${ }^{7}$ However, it suffers from certain drawbacks, most importantly the availability of the starting material as being very expensive and difficult of access. According to the literature report the synthesis of 2-fluoro-6-chloro-9H-purine can be achieved in 61\% yield starting from 2-amino-6-chloropurine which is also an expensive chemical. Therefore, a synthetic route starting from more readily available and cheaper substrates was envisioned for library synthesis. Halide substituents in the purine system display a leaving group ability which decreases in the series $\mathrm{C}-6>\mathrm{C}-2 .{ }^{18}$ Hence, if the difference in reactivity is sufficiently large, 2,6-dichloropurine (1) can also be used as the starting material. This compound can be synthesized starting from xanthine - a cheap starting material - following a facile literature-known protocol, however in $47 \%$ yield. ${ }^{19}$ Nucleophilic substitutions on this compound have been reported in the literature. For example, the reaction of 2,6-dichloropurine with cyclohexylamine took place selectively in the 6-position in $76 \%$ yield using pentanol (alternatively n-butanol can be used) as solvent at $70{ }^{\circ} \mathrm{C} .{ }^{20}$ Also in our hands this nucleophilic substitution on 2,6-dichloropurine worked well and selectively at the more electrophilic C6 center. Substitution of the second chlorine by aromatic amines is also a literature-known process and usually proceeds under acid catalyzed conditions (TMSCl, amine, n- $\mathrm{BuOH}, 120{ }^{\circ} \mathrm{C}$ ). ${ }^{21}$ Under these conditions, we could introduce 4-morpholinoaniline at $\mathrm{C} 2$ to obtain reversine $\mathbf{3}$ in $63 \%$ yield (Scheme 1). Although the overall yield of this 2 step synthesis of reversine is lower than the reported synthesis (48\% compared to $61 \%$ ), this method is much more practical for the synthesis of a library of compounds due to the significantly better accessibility of the starting material (2,6-dichloropurine) from a cheap precursor. 


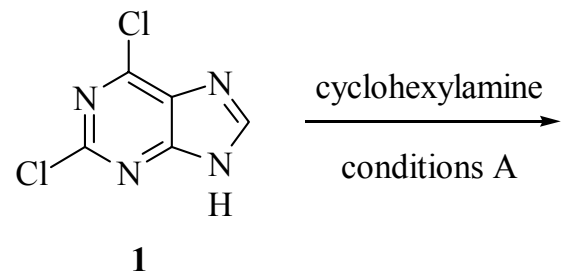

1

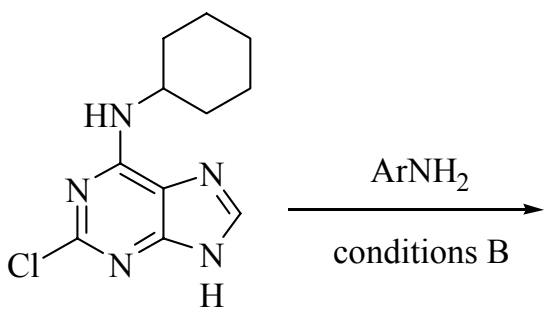

$2,76 \%$

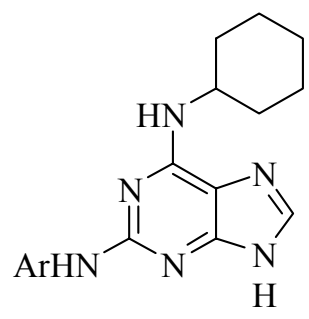

3: $\mathrm{Ar}=4$-morpholino- $\mathrm{C}_{6} \mathrm{H}_{4} 63 \%$

4: $\mathrm{Ar}=4-\mathrm{MeO}-\mathrm{C}_{6} \mathrm{H}_{4} 93 \%$

Scheme 1. Synthesis of reversine. A: cyclohexylamine (1.1 equiv) in n-pentanol, $70{ }^{\circ} \mathrm{C}, 4 \mathrm{hr}, \mathrm{N}_{2}$. B: $\mathrm{ArNH}_{2}$ (2.5 equiv), TMSCl (1-3 drops) in dry n-BuOH, $120{ }^{\circ} \mathrm{C}, 14 \mathrm{~h}$.

With the protocol described above, a series of reversine analogs was prepared. Initially, the cyclohexylamine substituent in 6-position was kept constant and the arylamino-substituent in 2-position was exchanged for $p$-anisidine (this is the arylamino substituent present in cardiogenol C) as the most active group within the cardiogenol series. Derivative 4 was synthesized in $70 \%$ yield over two steps (Scheme 1). Next, ethanolamine was introduced into the 6-position (as in the cardiogenols) and 4-morpholinoaniline into the 2-position reflecting the reversine substitution pattern. First, ethanolamine was introduced according to the literature protocol in $57 \%$ yield (Scheme 2$)^{21}$ and the intermediate reacted with 4-morpholinoaniline in $90 \%$ yield to give 6 (51\% yield over 2 steps, Table 1, entry 1). Both of these compounds $(4,6)$ can be considered as hybrids between reversine and cardiogenol $\mathrm{C}$ as a result of substrate interconversion of the two lead structures. Interesting insights into the SAR of these two lead compounds were expected.<smiles>Clc1nc(Cl)c2nc[nH]c2n1</smiles>

1<smiles>OCCNc1nc(Cl)nc2[nH]cnc12</smiles>

$5,57 \%$

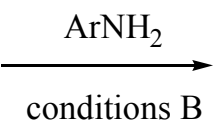

$6-16,40-90 \%$

Scheme 2. Synthesis of purine analogues of cardiogenols. A: Ethanolamine (1.1 equiv), DIPEA (1.2 equiv), $70^{\circ} \mathrm{C}, 4 \mathrm{hr}, \mathrm{N}_{2}$. B: $\operatorname{ArNH}_{2}$ (2.5 equiv) $\mathrm{TMSCl}(2 \mathrm{drops}), 120^{\circ} \mathrm{C}, 14 \mathrm{~h}$

Next, purine compounds were synthesized carrying the arylamino-substituents also present in cardiogenols A-D (Figure 2) in 2-position as well as ethanolamine in 6-position. 
<smiles>OCCNc1ccnc(Nc2ccc(Nc3ccccc3)cc2)n1</smiles>

cardiogenol A<smiles>COc1ccc(Nc2nccc(NCCO)n2)cc1</smiles>

cardiogenol $\mathbf{C}$<smiles>OCCNc1ccnc(Nc2ccc(Oc3ccccc3)cc2)n1</smiles>

cardiogenol B<smiles>OCCNc1ccnc(Nc2ccc(/C=C/c3ccccc3)cc2)n1</smiles>

cardiogenol D

Figure 2. Cardiogenols.

Compounds 7-10 were obtained in good yield and can be considered as "purine analogs" of the cardiogenols.

Besides the arylamino-substituents present in cardiogenols, a series of other aniline derivatives was introduced subsequently in 2-position (Scheme 2). Compounds 11-16 were obtained in fair to excellent yields (Table 1, 40-90\%). No clear trend regarding the efficiency of the nucleophilic substitution was observed. So far, the best yields were achieved when 4morpholinoaniline, $m$-anisidine, and 4-fluoroaniline were used as nucleophile in the second step (entries 1, 7, 11). On the other hand, modest yields were obtained using 3-chloroaniline and 4phenylethylaniline (entries 6, 8). Interestingly, 2-fluoro-, 2-chloro-, and 2-bromo-substituted anilines did not give the desired product probably due to steric hindrance. In contrast, substitution of $\mathrm{C} 2$ chlorine by $m$-halo substituted anilines ( $\mathrm{F}$-, $\mathrm{Cl}$-, Br-substituted anilines) was generally successful (entries 9, 10, 11). Among such 4-substituted haloanilines, 4-fluoroaniline was successfully used as the C2-substituent to give product 16 (entry 11) with 89\% yield. Unfortunately, 4-chloro and 4-bromo-substituted anilines did not give the desired products.<smiles>OCCNc1nc(Cl)nc2[nH]cnc12</smiles>

5<smiles>Cc1nc(N)nc2[nH]cnc12</smiles> 
Table 1. Preparation of structurally modified cardiogenols 6-16

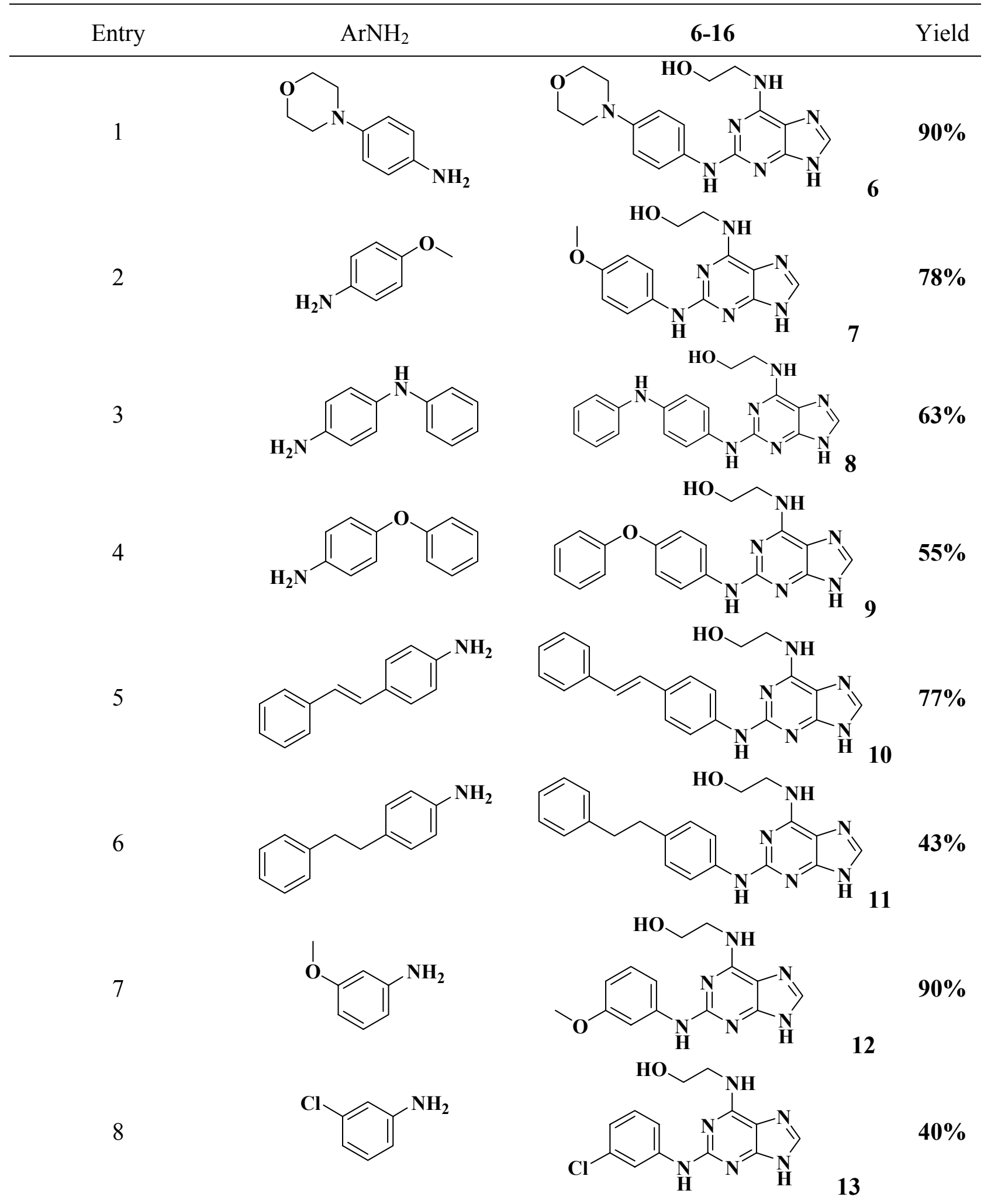


9<smiles>Nc1cccc(F)c1</smiles>

10<smiles>Nc1cccc(Br)c1</smiles>

11

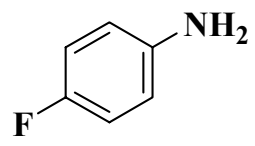

$56 \%$

14

$54 \%$

15

$89 \%$

Compounds 18 and 19 are additional interesting examples since they possess propanolamine as C6 substituent instead of ethanolamine (Scheme 3). Comparison of biological activity with the compounds containing ethanolamine might provide information of the effect of chain length on biological activity.<smiles>Clc1nc(Cl)c2nc[nH]c2n1</smiles>

1<smiles>OCCCNc1nc(Cl)nc2[nH]cnc12</smiles>

$17,64 \%$

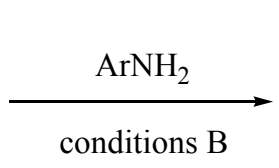

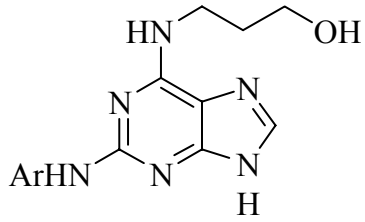

18: $\mathrm{Ar}=4-\mathrm{MeO}-\mathrm{C}_{6} \mathrm{H}_{4}, 84 \%$

19: $\mathrm{Ar}=4-$ Morpholino- $\mathrm{C}_{6} \mathrm{H}_{4}, 77 \%$

Scheme 3. Conditions A: propanolamine (1.1 equiv), DIPEA (1.1 equiv) in $\mathrm{n}-\mathrm{BuOH}, 70{ }^{\circ} \mathrm{C}, 4 \mathrm{~h}$, $\mathrm{N}_{2}$. Conditions B: $\mathrm{ArNH}_{2}$ (2.5 equiv) TMSCl (1 drops) in dry n-BuOH, $120^{\circ} \mathrm{C}, 14 \mathrm{~h}$.

As can be seen from Scheme 3, reaction of 2,6-dichloropurine with propanolamine gave intermediate 17 in good yield of 64\%. Nucleophilic substitution of the crude material with two different aromatic amines gave the desired products 18 and 19, again with good yields of 84\% and $77 \%$, respectively.

\section{Results of biological testing}

As already reported in the literature, reversine was able to induce myogenic lineage committed cells ( $\mathrm{C} 2 \mathrm{C} 12$ cells) to become multipotent progenitor cells (representing a de-differentiation process), which could then be re-differentiated into osteoblasts and adipocytes. ${ }^{7}$ The activity of reversine was determined by a 4 day-treatment of the cells with reversine, before established 
osteogenesis-inducing conditions or factors to drive the differentiation of adipocytes were applied. An also possible direct trans-differentiation process was excluded.

Here, we first attempted to reproduce the effect of reversine $\mathbf{3}$ on the differentiation properties of $\mathrm{C} 2 \mathrm{C} 12$ skeletal myoblasts. Figure 3 shows that low concentrations of reversine inhibit the differentiation of $\mathrm{C} 2 \mathrm{C} 12$ myoblasts to mature skeletal muscle fibres (skeletal myotubes), which is in agreement with the literature reports. ${ }^{7}$ Thus, it can be observed that $2 \mathrm{nM}$ reversine strongly inhibited the formation of myotubes as compared to the control experiment. At this low reversine concentration, there were no signs of cell toxicity. However, at higher concentrations, reversine significantly decreased cell density, and at a concentration of $2 \mu \mathrm{M}$, hardly any viable cells were visible after 4 days of treatment.

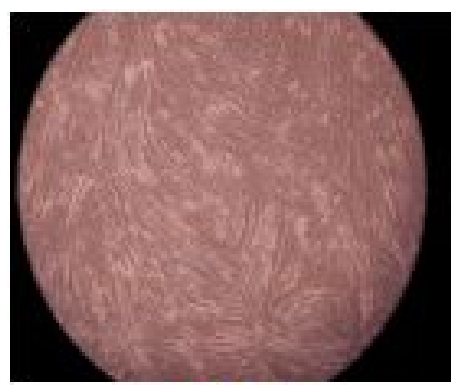

control

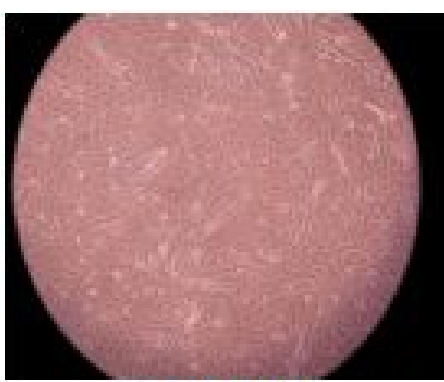

$2 \mathrm{nM}$

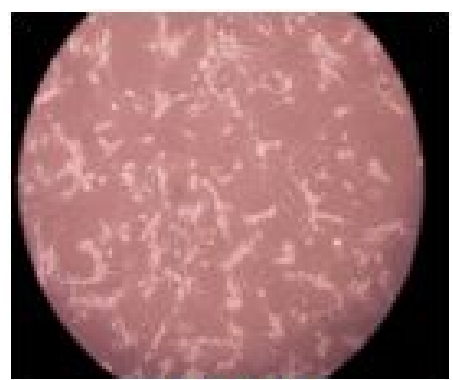

$20 \mathrm{nM}$

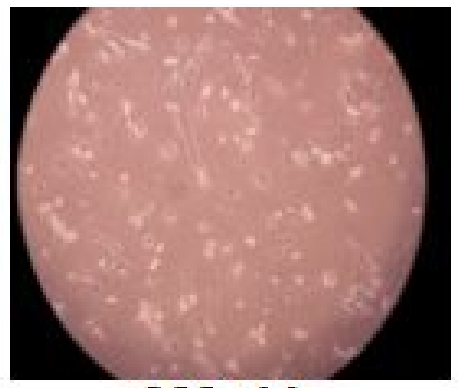

$200 \mathrm{nM}$

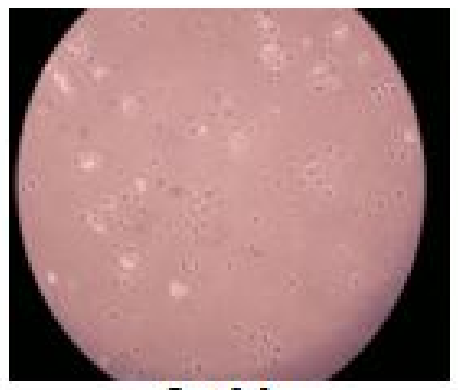

$2 \mu \mathrm{M}$

Figure 3. Reversine treated $\mathrm{C} 2 \mathrm{C} 12$ myoblasts.

After confirming that reversine is active on our studied $\mathrm{C} 2 \mathrm{C} 12$ cell cultures consistent with the literature reports, ${ }^{7,22}$ we performed an initial study of its potential cardiomyogenic activity. Therefore, the properties of currents carried by voltage-gated sodium channels were compared between reversine-treated and control $\mathrm{C} 2 \mathrm{C} 12$ cells. Figure 4 shows two effects of reversine on the sodium currents: First, the sodium currents of reversine treated cells showed an increased resistance against blocking by tetrodotoxin (TTX), a skeletal muscle sodium channel specific blocker (left figure part). Secondly, reversine significantly slowed the kinetics of the sodium currents (right figure part). Both results are consistent with an up-regulation of the expression of the cardiac sodium channel isoform $\mathrm{Na}_{\mathrm{v}} 1.5$, versus the normally predominantly expressed skeletal muscle isoform $\mathrm{Na}_{\mathrm{v}} 1.4$, in reversine-treated $\mathrm{C} 2 \mathrm{C} 12$ cells. Thus, reversine seems to 
induce cardiomyogenic function in $\mathrm{C} 2 \mathrm{C} 12$ skeletal myoblasts. At present, however, it cannot be judged if this effect of reversine is simply produced by a de-differentiation of $\mathrm{C} 2 \mathrm{C} 12$ cells, or a partial trans-differentiation of $\mathrm{C} 2 \mathrm{C} 12$ cells into cardiomyocytes.

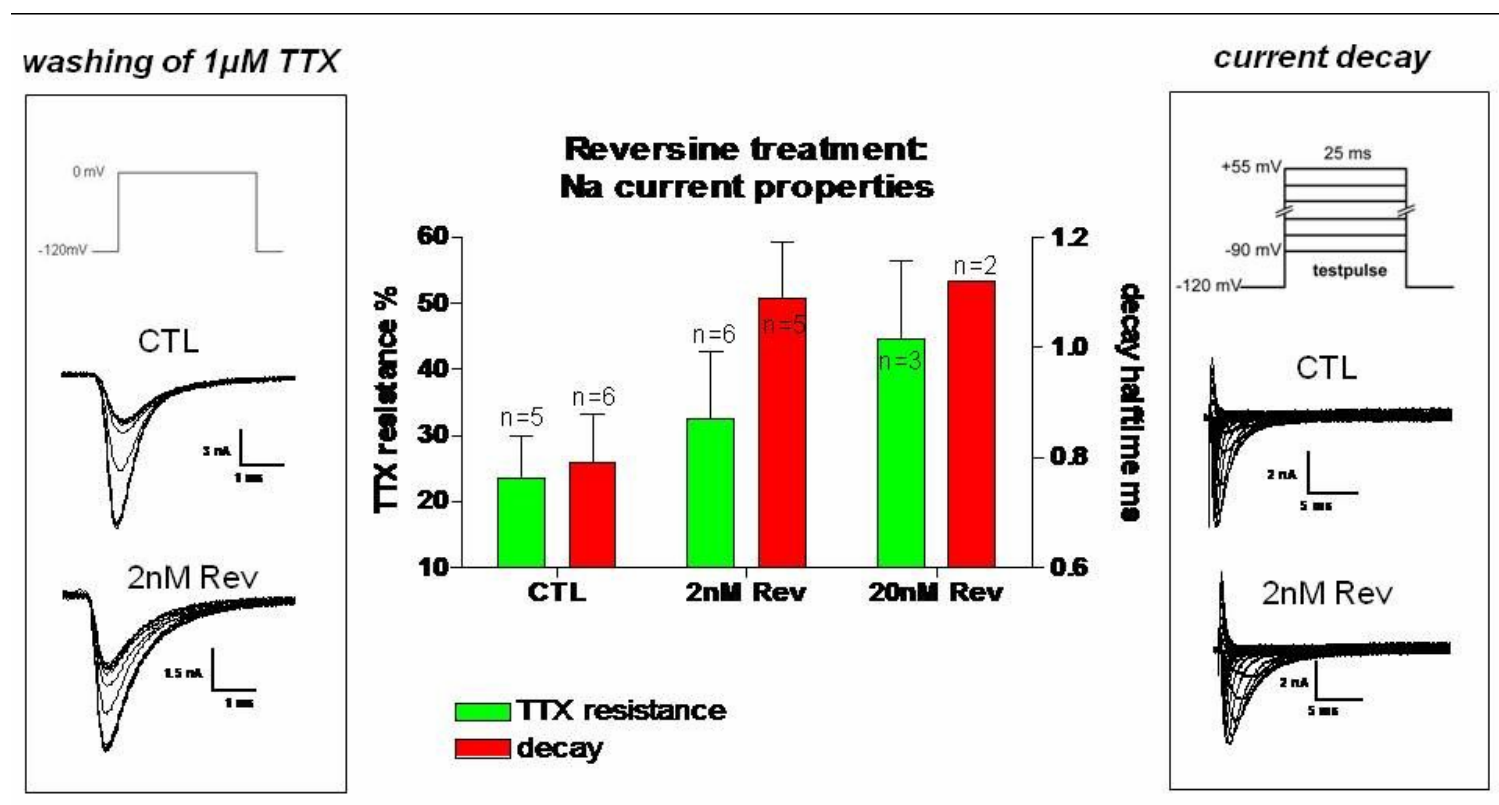

Figure 4. Na-current properties of reversine treated $\mathrm{C} 2 \mathrm{C} 12$ cells.

Newly synthesized compound $\mathbf{4}$ showed a similar activity on the morphology of C2C12 cells as reversine. Compound $\mathbf{8}$ generated by trend similar effects on the sodium currents compared to reversine. Moreover, it significantly speeded the activation of currents through voltage-gated calcium channels (data not shown). This may be interpreted as a moderate shift towards more cardiac-like calcium current properties.

Summarizing, we have developed a facile and rapid synthetic strategy to reversine analogs by site-selective nucleophilic attack at 2,6-dichloropurine. Representatives of the compound library prepared displayed interesting biological activities indicating a trans-differentiation potential of such structures towards cardiomyogenesis.

\section{Experimental Section}

General. Unless otherwise noted, chemicals were purchased from commercial suppliers and used without further purification. Melting points were determined using a Kofler-type Leica Galen III micro hot stage microscope and are uncorrected. HR-MS was carried out by E. Rosenberg at the Vienna University of Technology, Institute for Chemical Technologies and Analytics. All samples were analyzed by LC-IT-TOF-MS in only positive ion detection mode 
with the recording of MS and MS/MS spectra. NMR-spectra were recorded either in DMSO- $\mathrm{d}_{6}$ or in $\mathrm{CD}_{3} \mathrm{OD}$ on a Bruker AC $200(200 \mathrm{MHz})$ spectrometer and chemical shifts are reported in ppm. ${ }^{1} \mathrm{H}$ and ${ }^{13} \mathrm{C}$ were recorded on a Bruker $\mathrm{AC} 400(400 \mathrm{MHz})$ spectrometer in case of reversine. In most cases some ${ }^{13} \mathrm{C}$ signals were not visible due to slow relaxation.

\section{General procedure $A$}

2,6-Dichloropurine (1 equiv), aliphatic amine (1.1 equiv), and DIPEA (1.2 equiv) were dissolved in $\mathrm{n}-\mathrm{BuOH}$ under nitrogen atmosphere. Then the reaction mixture was heated at $70{ }^{\circ} \mathrm{C}$ for $4 \mathrm{~h}$. The reaction was monitored by TLC and found to be finished after $4 \mathrm{~h}$. Then the reaction mixture was cooled to r.t. A precipitate appeared upon cooling. The reaction mixture was kept in the freezer for $2 \mathrm{~h}$. Pure product was obtained by filtration and washing with cold $\mathrm{n}-\mathrm{BuOH}$.

\section{General procedure B}

Compounds (1 equiv) obtained according to general procedure $\mathrm{A}$ and the aromatic amine (2.5 equiv) were dissolved in dry $\mathrm{n}-\mathrm{BuOH}$ in a screw-cap vial and 1-3 drops of TMSCl were added. Then the reaction mixture was heated at $120{ }^{\circ} \mathrm{C}$ for $14 \mathrm{~h}$ in a heating block. A precipitate was formed and pure product was obtained by filtration and washing with cold EtOH or EtOAc.

2-Chloro- $\boldsymbol{N}$-cyclohexyl-9H-purin-6-amine (2). ${ }^{21}$ 2,6-Dichloropurine 1 (100 mg, 0.53 mmol, 1 equiv) and cyclohexylamine (58 mg, $0.58 \mathrm{mmol}, 1.1$ equiv) were heated at $70{ }^{\circ} \mathrm{C}$ in n-pentanol $(3$ $\mathrm{mL}$ ) as solvent for $4 \mathrm{~h}$ under $\mathrm{N}_{2}$ atmosphere. The reaction was monitored by TLC and was completed after $4 \mathrm{~h}$. A colorless precipitate was formed upon cooling. The precipitated was filtered and washed with cold n-pentanol to give the desired product 2. Yield: $53 \%$ (70 mg, 0.28 mmol). Appearance: colorless solid. Mp: $291{ }^{\circ} \mathrm{C}$. TLC: $\mathrm{R}_{\mathrm{f}}=0.83$ (Toluene: $i$-PrOH $=3: 1$ ). ${ }^{1} \mathrm{H}$ NMR (DMSO- $\left.d_{6}, 200 \mathrm{MHz}\right): \delta=1.09-2.05(\mathrm{~m}, 10 \mathrm{H}), 3.87-4.10(\mathrm{bs}, 1 \mathrm{H}), 7.86-8.03$ (bs, $\left.1 \mathrm{H}\right)$, $8.09(\mathrm{~s}, 1 \mathrm{H}) .{ }^{13} \mathrm{C}$ NMR $\left(\mathrm{DMSO}-d_{6}, 50 \mathrm{MHz}\right): \delta=24.7(\mathrm{t}), 25.1(\mathrm{t}), 32.1(\mathrm{t}), 48.6(\mathrm{~d}), 116.4(\mathrm{~s})$, 136.1 (d), 139.6 (s), 152.9 (s).

$\boldsymbol{N}^{6}$-Cyclohexyl- $\boldsymbol{N}^{2}$-[(4-morpholinyl)phenyl]-9H-purin-2,6-diamine (3). ${ }^{7}$ Compound 2 (341 $\mathrm{mg}, 1.35 \mathrm{mmol}, 1$ equiv), 4-morpholinoaniline (604 mg, $3.38 \mathrm{mmol}, 2.5$ equiv), and TMSCl (2 drops) were dissolved in $\mathrm{n}-\mathrm{BuOH}(4 \mathrm{~mL})$ and reacted according to general procedure $\mathrm{B}$. Pure product 3 was obtained after filtration and washing with cold n-BuOH. Yield: 63\% (335 mg, $0.85 \mathrm{mmol})$. Appearance: colorless solid. Mp: melting started at $285{ }^{\circ} \mathrm{C}$, decomposition at 305 ${ }^{\circ} \mathrm{C}$. TLC: $\mathrm{R}_{\mathrm{f}}=0.44$ (Toluene: $\left.i-\mathrm{PrOH}=6: 1\right) .{ }^{1} \mathrm{H}$ NMR (DMSO- $\left.d_{6}, 400 \mathrm{MHz}\right): \delta=1.06-2.06(\mathrm{~m}$, $10 \mathrm{H}), 3.05$ (t, $J=3.9 \mathrm{~Hz}, 4 \mathrm{H}), 3.74$ (t, $J=4.2 \mathrm{~Hz}, 4 \mathrm{H}), 3.97-4.15$ (bs, 1H), 6.89 (d, $J=8.8 \mathrm{~Hz}$, $2 \mathrm{H}), 7.57(\mathrm{~d}, J=8.6 \mathrm{~Hz}, 2 \mathrm{H}), 8.09(\mathrm{~s}, 1 \mathrm{H}), 9.08(\mathrm{~s}, 1 \mathrm{H}) .{ }^{13} \mathrm{C}$ NMR (DMSO-d, $\mathrm{CF}_{3} \mathrm{COOH}$, $100 \mathrm{MHz}): \delta=23.9(\mathrm{t}), 30.7(\mathrm{t}), 52.7(\mathrm{~d}), 55.5(\mathrm{t}), 63.7(\mathrm{t}), 110.0(\mathrm{~s}), 113.4(\mathrm{~s}), 115.7(\mathrm{~s}), 118.5$ (s), $121.4(\mathrm{~d}), 123.6$ (d), 136.7 (d), 139.4(s), 149.3 (s).

$\boldsymbol{N}^{\mathbf{6}}$-Cyclohexyl- $\boldsymbol{N}^{\mathbf{2}}$-(4-methoxyphenyl)-9H-purine-2, 6-diamine (4). ${ }^{21}$ Compound 2 (200 mg, $0.79 \mathrm{mmol}, 1$ equiv), 4-methoxyaniline (244.6 mg, $1.99 \mathrm{mmol}, 2.5$ equiv) and TMSCl (2 drops) were dissolved in $\mathrm{n}$-butanol $(3 \mathrm{~mL})$ and reacted according to general procedure $\mathrm{B}$. A precipitate 
was formed and pure product 4 was obtained by filtration and washing with EtOH. Yield: 93\% (217 mg, $0.64 \mathrm{mmol}$ ). Appearance: pink solid. Mp: $155-195{ }^{\circ} \mathrm{C}$. TLC: $\mathrm{R}_{\mathrm{f}}=0.44$ (Toluene: $i$ $\operatorname{PrOH}=6: 1) .{ }^{1} \mathrm{H}$ NMR $\left(\mathrm{DMSO}-d_{6}, 200 \mathrm{MHz}\right): \delta=1.05-2.06(\mathrm{~m}, 11 \mathrm{H}), 3.73(\mathrm{~s}, 3 \mathrm{H}), 4.02(\mathrm{~s}, 1 \mathrm{H})$, $6.87(\mathrm{~d}, J=8.9 \mathrm{~Hz}, 2 \mathrm{H}), 7.60(\mathrm{~d}, J=8.8 \mathrm{~Hz}, 2 \mathrm{H}), 8.03(\mathrm{~s}, 1 \mathrm{H}), 8.12(\mathrm{~s}, 1 \mathrm{H}), 9.13(\mathrm{~s}, 1 \mathrm{H}) .{ }^{13} \mathrm{C}$ NMR (DMSO- $\left.d_{6}, 50 \mathrm{MHz}\right): \delta=24.7(\mathrm{t}), 25.1(\mathrm{t}), 32.4(\mathrm{t}), 49.3(\mathrm{~d}), 55.3(\mathrm{q}), 108.9(\mathrm{~s}), 113.7(\mathrm{~d})$, 121.0 (d) 133.4 (s), 137.9 (d), 149.9 (s), 151.7 (s), 154.5 (s).

2-(2-Chloro-9H-purin-6-ylamino)ethanol (5). Compound 1 (152.5 mg, $0.81 \mathrm{mmol}, 1$ equiv), ethanolamine (54 mg, $0.89 \mathrm{mmol}, 1.1$ equiv) and DIPEA (128 mg, $0.99 \mathrm{mmol}, 1.2 \mathrm{equiv}$ ) were dissolved in $\mathrm{n}-\mathrm{BuOH}(5 \mathrm{~mL})$ and reacted according to general procedure A. A precipitate was formed and pure product 5 was obtained by filtration and washing with $\mathrm{n}-\mathrm{BuOH}$. This compound was used for $2^{\text {nd }}$ steps without further purifications. Yield: $57 \%$ (98 mg, $0.46 \mathrm{mmol}$ ). Appearance: colorless solid. Mp: $210-215^{\circ} \mathrm{C}$. TLC: $\mathrm{R}_{\mathrm{f}}=0.21$ (Toluene: $i$-PrOH $=3: 1$ ). ${ }^{1} \mathrm{H}$ NMR (DMSO- $\left.d_{6}, 200 \mathrm{MHz}\right): \delta=3.44-3.68(\mathrm{bs}, 4 \mathrm{H}), 8.03(\mathrm{~s}, 1 \mathrm{H}), 8.15(\mathrm{~s}, 1 \mathrm{H}) .{ }^{13} \mathrm{C}$ NMR (DMSO- $d_{6}$, 50MHz): $\delta=42.7(\mathrm{t}), 59.5(\mathrm{t}), 116.1(\mathrm{~s}), 140.1(\mathrm{~d}), 152.4(\mathrm{~s}), 152.7(\mathrm{~s}), 154.4(\mathrm{~s})$.

2-[2-[(4-Morpholinyl)phenylamino]-9H-purin-6-ylamino]ethanol (6). Compound 5 (60 mg, $0.28 \mathrm{mmol}, 1$ equiv) and 4-morpholinoaniline (125 mg, $0.70 \mathrm{mmol}, 2.5$ equiv) were dissolved in $\mathrm{n}-\mathrm{BuOH}(2 \mathrm{~mL})$ and reacted according to general procedure B. Pure product 6 was obtained by filtering the formed precipitate and washing with cold ethanol. Yield: $90 \%$ (90 mg, $0.25 \mathrm{mmol}$ ). Appearance: colorless solid. Mp: $173-176{ }^{\circ} \mathrm{C}$. TLC: $\mathrm{R}_{\mathrm{f}}=0.10$ (Toluene: $i$-PrOH $=3: 1$ ). ${ }^{1} \mathrm{H}$ NMR (DMSO- $\left.d_{6}, 200 \mathrm{MHz}\right): \delta=3.02-3.29$ (bs, 4H), 3.48-3.68 (bs, 4H), 3.71-3.89 (s, 4H), 7.17 (d, $J=$ $8.2 \mathrm{~Hz}, 2 \mathrm{H}), 7.58(\mathrm{~d}, J=8.6 \mathrm{~Hz}, 2 \mathrm{H}), 8.50(\mathrm{~s}, 1 \mathrm{H}), 9.03(\mathrm{~s}, 1 \mathrm{H}), 9.93(\mathrm{~s}, 1 \mathrm{H}) .{ }^{13} \mathrm{C}$ NMR (DMSO$\left.d_{6}, 50 \mathrm{MHz}\right): \delta=43.5(\mathrm{t}), 50.1(\mathrm{t}), 59.3(\mathrm{t}), 65.4(\mathrm{t}), 105.9(\mathrm{~s}), 117.1(\mathrm{~d}), 121.3(\mathrm{~d}), 122.0(\mathrm{~s})$, 139.6 (d), 148.2 (s), 151.7 (s). HR-MS: Predicted $[\mathrm{MH}]^{+}=356.1829$; Measured $[\mathrm{MH}]^{+}=$ 356.1850. Diff. in ppm $=5.8$.

2-[2-(4-Methoxyphenylamino)-9H-purin-6-ylamino]ethanol (7). Compound 5 (78 mg, 0.37 mmol, 1 equiv) and 4-methoxyaniline (112 mg, $0.92 \mathrm{mmol}, 2.5$ equiv) were dissolved in $\mathrm{n}$ $\mathrm{BuOH}(2 \mathrm{~mL})$ and reacted according to general procedure $\mathrm{B}$. A precipitate was formed and pure product 7 was obtained by filtration and washing with cold ethanol. Yield: $78 \%$ (78 mg, 0.27 mmol). Appearance: pink solid. Mp: $241-245{ }^{\circ} \mathrm{C}$. TLC: $\mathrm{R}_{\mathrm{f}}=0.1$ (Toluene: $i$-PrOH $=3: 1$ ). ${ }^{1} \mathrm{H}$ NMR (DMSO- $\left.d_{6}, 200 \mathrm{MHz}\right): \delta=3.47-3.70(\mathrm{~s}, 4 \mathrm{H}), 3.72(\mathrm{~s}, 3 \mathrm{H}), 6.85(\mathrm{~d}, J=8.6 \mathrm{~Hz}, 2 \mathrm{H}), 7.56$ $(\mathrm{d}, J=8.6 \mathrm{~Hz}, 2 \mathrm{H}), 7.75(\mathrm{~s}, 1 \mathrm{H}), 8.00(\mathrm{~s}, 1 \mathrm{H}), 8.97(\mathrm{~s}, 1 \mathrm{H}) .{ }^{13} \mathrm{C}$ NMR (DMSO- $\left.d_{6}, 50 \mathrm{MHz}\right): \delta=$ 55.3 (t), 59.8 (q), 113.5 (d), 120.8 (d), 133.8 (s), 137.6 (d), 145.9 (s), $153.3(\mathrm{~s}), 153.9$ (s), 155.1 (s). HR-MS: Predicted $[\mathrm{MH}]^{+}=301.1413$; Measured $[\mathrm{MH}]^{+}=301.1428$. Diff. in ppm $=4.9$.

2-[2[(4-(Phenylamino)phenylamino]-9H-purin-6-ylamino]ethanol (8). Compound 5 (76 mg, $0.35 \mathrm{mmol}, 1$ equiv) and 4-aminodiphenylamine (163 $\mathrm{mg}, 0.88 \mathrm{mmol}, 2.5$ equiv) were dissolved in $\mathrm{n}-\mathrm{BuOH}(2 \mathrm{~mL})$ and reacted according to general procedure B. Pure product 8 was obtained by filtration of the formed precipitate and washing with cold ethanol. Yield: $63 \%(80 \mathrm{mg}, 0.22$ mmol). Appearance: beige solid. Mp: $260{ }^{\circ} \mathrm{C}$. TLC: $\mathrm{R}_{\mathrm{f}}=0.23$ (Toluene: $i$-PrOH $=6: 1$ ). ${ }^{1} \mathrm{H}$ NMR (DMSO- $\left.d_{6}, 200 \mathrm{MHz}\right): \delta=3.43-3.75(\mathrm{bs}, 4 \mathrm{H}), 6.74(\mathrm{t}, J=6.7 \mathrm{~Hz}, 1 \mathrm{H}), 7.02(\mathrm{t}, J=9.1 \mathrm{~Hz}, 5 \mathrm{H})$, $7.18(\mathrm{t}, J=6.9 \mathrm{~Hz}, 2 \mathrm{H}), 7.58(\mathrm{~d}, J=8.2 \mathrm{~Hz}, 2 \mathrm{H}), 8.00(\mathrm{~s}, 1 \mathrm{H}), 8.11(\mathrm{~s}, 2 \mathrm{H}), 9.27(\mathrm{~s}, 1 \mathrm{H}) .{ }^{13} \mathrm{C}$ 
NMR (DMSO- $\left.d_{6}, 50 \mathrm{MHz}\right): \delta=43.1(\mathrm{t}), 59.7(\mathrm{t}), 115.5(\mathrm{~d}), 118.5(\mathrm{~d}), 121.0(\mathrm{~d}), 129.2(\mathrm{~d}), 133.0$ (d), 137.8 (s), 138.4 (d), 144.6 (s), 149.5 (s), 152.7 (s), 154.1 (s). HR-MS: Predicted [MH] ${ }^{+}=$ 362.1729; Measured $[\mathrm{MH}]^{+}=362.1744$. Diff. in $\mathrm{ppm}=4.1$.

2-[2-(4-Phenoxyphenylamino)-9H-purin-6-ylamino]ethanol (9). Compound 5 (70 mg, 0.33 mmol, 1 equiv) and 4-phenoxyaniline (152 mg, $0.82 \mathrm{mmol}, 2.5$ equiv) were dissolved in $\mathrm{n}$ $\mathrm{BuOH}$ and reacted according to general procedure B. Pure product 9 was obtained by filtration of the obtained precipitate and washing with cold ethanol. Yield: 55\% (65 mg, $0.18 \mathrm{mmol}$ ). Appearance: light yellow solid. Mp: $278{ }^{\circ} \mathrm{C}$. TLC: $\mathrm{R}_{\mathrm{f}}=0.22$ (Toluene: $i$-PrOH $=6: 1$ ). ${ }^{1} \mathrm{H}$ NMR (DMSO- $\left.d_{6}, 200 \mathrm{MHz}\right): \delta=3.49-3.75(\mathrm{~s}, 4 \mathrm{H}), 6.89-7.13(\mathrm{~m}, 6 \mathrm{H}), 7.36(\mathrm{t}, J=7.8 \mathrm{~Hz}, 2 \mathrm{H}), 7.76(\mathrm{~d}$, $J=8.9 \mathrm{~Hz}, 2 \mathrm{H}), 8.09(\mathrm{~s}, 1 \mathrm{H}), 8.21(\mathrm{~s}, 1 \mathrm{H}), 9.39(\mathrm{~s}, 1 \mathrm{H}) .{ }^{13} \mathrm{C} \mathrm{NMR}\left(\mathrm{DMSO}-d_{6}, 50 \mathrm{MHz}\right): \delta=43.1$ (t), 59.5 (t), 117.5 (d), 119.5 (d), 120.9 (d), 122.6 (d), 130.0 (d), 136.4 (s), 137.9 (s), 150.4 (s), $152.9(\mathrm{~s}), \quad 154.7$ (s), 157.7 (s). HR-MS: Predicted $[\mathrm{MH}]^{+}=363.1569 ;$ Measured $[\mathrm{MH}]^{+}=363.1576$. Diff. in $\mathrm{ppm}=1.9$.

(E)-2-[2-[4-(2-phenylethenyl)phenylamino]-9H-purin-6-ylamino]ethanol (10). Compound 5 (25 mg, $0.12 \mathrm{mmol}, 1$ equiv) and 4-styrylaniline (57 $\mathrm{mg}, 0.29 \mathrm{mmol}, 2.5$ equiv) were dissolved in $\mathrm{n}-\mathrm{BuOH}(1 \mathrm{~mL})$ and reacted according to general procedure $\mathrm{B}$ but with 1 drop of TMSCl. Pure product 10 was obtained by filtation of the obtained precipitate and washing with cold ethanol. Yield: 77\% (34 mg, $0.09 \mathrm{mmol}$ ). Appearance: yellow solid. Mp: 265-270 ${ }^{\circ} \mathrm{C}$. TLC: $\mathrm{R}_{\mathrm{f}}=0.18$ (Toluene: $i$-PrOH $=6: 1) .{ }^{1} \mathrm{H}$ NMR (DMSO- $\left.d_{6}, 200 \mathrm{MHz}\right): \delta=3.50-3.73(\mathrm{bs}, 4 \mathrm{H}), 7.01-7.18(\mathrm{~m}$, $3 \mathrm{H}), 7.24(\mathrm{~d}, J=7.0 \mathrm{~Hz}, 1 \mathrm{H}), 7.34(\mathrm{t}, J=7.3 \mathrm{~Hz}, 3 \mathrm{H}), 7.55$ (t, $J=7.9 \mathrm{~Hz}, 3 \mathrm{H}), 7.79(\mathrm{~d}, J=8.6$ $\mathrm{Hz}, 2 \mathrm{H}), 7.99(\mathrm{~s}, 1 \mathrm{H}), 8.25(\mathrm{~s}, 1 \mathrm{H}), 9.42(\mathrm{~s}, 1 \mathrm{H}) .{ }^{13} \mathrm{C}$ NMR (DMSO-d $\left.6,50 \mathrm{MHz}\right): \delta=43.2(\mathrm{t})$, 59.5 (t), 108.8 (s), 116.5 (d), 119.7 (d), 126.2 (d), 126.8 (d), 127.1 (d), 128.2 (d), 128.6 (d), 130.4 (s), 137.6 (s), 138.2 (d), 139.6 (s), 149.6 (s), 152.5 (s), 154.1 (s). HR-MS: Predicted [MH] ${ }^{+}=$ 373.1768; Measured $[\mathrm{MH}]^{+}=373.1771$. Diff. in $\mathrm{ppm}=0.8$.

2-[2[(4-Phenylethyl)phenylamino]-9H-purin-6-ylamino]ethanol (11). Compound 5 (50 mg, $0.23 \mathrm{mmol}, 1$ equiv) and 4-phenylethylaniline (114 mg, $0.58 \mathrm{mmol}, 2.5$ equiv) were dissolved in $\mathrm{n}-\mathrm{BuOH}(2 \mathrm{~mL})$ and reacted according to general procedure B. Pure product 11 was obtained by filtration of the obtained precipitate and washing with cold ethanol. Yield: 43\% (37 mg, 0.10 mmol). Appearance: light yellow solid. Mp: $269-272{ }^{\circ} \mathrm{C}$. $\mathrm{TLC}: \mathrm{R}_{\mathrm{f}}=0.17$ (Toluene: $i-\mathrm{PrOH}=$ 6:1). ${ }^{1} \mathrm{H}$ NMR $\left(\mathrm{CD}_{3} \mathrm{OD}, 200 \mathrm{MHz}\right): \delta=2.85-2.99(\mathrm{bs}, 4 \mathrm{H}), 3.69-3.84(\mathrm{~m}, 4 \mathrm{H}), 7.13-7.30(\mathrm{~m}$, $8 \mathrm{H}), 7.43(\mathrm{~d}, J=8.2 \mathrm{~Hz}, 2 \mathrm{H}), 8.17(\mathrm{~s}, 1 \mathrm{H}) .{ }^{13} \mathrm{C} \mathrm{NMR}\left(\mathrm{CD}_{3} \mathrm{OD}, 50 \mathrm{MHz}\right): \delta=36.8(\mathrm{t}), 37.5(\mathrm{t})$, $43.1(\mathrm{t}), 59.9$ (t), 120.8 (d), 125.4 (d), 127.6 (d), 128.0 (d), 128.6 (d), 136.1 (s), 137.3 (s), 138.2 (d), 139.2 (s), 141.5 (s), 153.2 (s). HR-MS: Predicted $[\mathrm{MH}]^{+}=375.1933$; Measured $[\mathrm{MH}]^{+}=$ 375.1943. Diff. in ppm $=2.6$.

2-[2-(3-Methoxyphenylamino)-9H-purin-6-ylamino]ethanol (12). Compound 5 (103 mg, 0.48 mmol, 1 equiv) and m-anisidine (148 mg, $1.20 \mathrm{mmol}, 2.5$ equiv) were dissolved in $\mathrm{n}-\mathrm{BuOH}$ (3 $\mathrm{mL}$ ) and reacted according to general procedure B upon addition of 3 drops of TMSCl. A precipitate was formed and pure product 12 was obtained by filtration and washing with EtOH. Yield: 90\% (129 mg, $0.43 \mathrm{mmol}$ ). Appearance: colorless solid. Mp: $241-245{ }^{\circ} \mathrm{C}$. TLC: $\mathrm{R}_{\mathrm{f}}=0.38$ (Toluene: $i$-PrOH $=3: 1)$. ${ }^{1} \mathrm{H}$ NMR $\left(\mathrm{DMSO}-d_{6}, 200 \mathrm{MHz}\right): \delta=3.52-3.71(\mathrm{bs}, 4 \mathrm{H}), 3.75(\mathrm{~s}, 3 \mathrm{H})$, 
$6.60(\mathrm{~d}, J=7.4 \mathrm{~Hz}, 1 \mathrm{H}), 7.11-7.29(\mathrm{~m}, 2 \mathrm{H}), 7.46(\mathrm{~s}, 1 \mathrm{H}), 8.61(\mathrm{~s}, 1 \mathrm{H}), 8.95(\mathrm{~s}, 1 \mathrm{H}), 9.93(\mathrm{~s}, 1 \mathrm{H})$.

${ }^{13} \mathrm{C}$ NMR (DMSO- $\left.d_{6}, 50 \mathrm{MHz}\right): \delta=43.5(\mathrm{t}), 54.9(\mathrm{t}), 59.2(\mathrm{~s}), 105.3$ (d), 108.1 (d), 111.9 (d), 129.4 (d), 139.0 (s), 140.3 (s), 151.6 (s), 153.3 (s), 159.5 (s). HR-MS: Predicted [MH] ${ }^{+}=$ 301.1408; Measured $[\mathrm{MH}]^{+}=301.1410$. Diff. in $\mathrm{ppm}=0.66$.

2-[2-(3-Chlorophenylamino)-9H-purin-6-ylamino]ethanol (13). Compound 5 (50 mg, 0.23 mmol, 1 equiv) and 3-chloroaniline (75 mg, $0.59 \mathrm{mmol}, 2.5$ equiv) were dissolved in $\mathrm{n}-\mathrm{BuOH}$ (2 $\mathrm{mL}$ ) and reacted according to general procedure B. A precipitate was formed and pure product 13 was obtained by filtration and washing with EtOAc. Yield: 40\% (122 mg, $0.40 \mathrm{mmol}$ ). Appearance: yellow solid. Mp: $269-270{ }^{\circ} \mathrm{C}$. TLC: $\mathrm{R}_{\mathrm{f}}=0.37$ (Toluene: $i-\mathrm{PrOH}=3: 1$ ). ${ }^{1} \mathrm{H}$ NMR (DMSO- $\left.d_{6}, 200 \mathrm{MHz}\right): \delta=3.50-3.79(\mathrm{bs}, 4 \mathrm{H}), 7.02(\mathrm{~d}, J=8.8 \mathrm{~Hz}, 1 \mathrm{H}), 7.31(\mathrm{t}, J=8.8 \mathrm{~Hz}, 1 \mathrm{H})$, $7.57(\mathrm{~d}, J=8.2 \mathrm{~Hz}, 1 \mathrm{H}), 7.99(\mathrm{~s}, 1 \mathrm{H}), 8.80(\mathrm{~s}, 2 \mathrm{H}), 9.95(\mathrm{~s}, 1 \mathrm{H}) .{ }^{13} \mathrm{C}$ NMR (DMSO- $\left.d_{6}, 50 \mathrm{MHz}\right)$ : $\delta=43.3(\mathrm{t}), 59.2(\mathrm{t}), 105.7$ (s), 117.6 (d), 118.6 (d), 121.5 (d), 130.1 (d), 132.9 (s), 138.1 (d), $141.3(\mathrm{~s}), 148.7(\mathrm{~s}), 151.5(\mathrm{~s}), 154.6(\mathrm{~s})$. HR-MS: Predicted $[\mathrm{MH}]^{+}=305.0912$; Measured $[\mathrm{MH}]^{+}=305.0925$. Diff. in $\mathrm{ppm}=4.26$.

2-[2-(3-Fluorophenylamino)-9H-purin-6-ylamino]ethanol (14). Compound 5 (50 mg, 0.23 mmol, 1 equiv.) and 3-fluoroaniline (65 mg, $0.59 \mathrm{mmol}, 2.5$ equiv) were dissolved in $\mathrm{n}-\mathrm{BuOH}$ (2 $\mathrm{mL}$ ) and reacted according to general procedure B. A precipitate was formed and pure product 14 was obtained by filtration and washing with EtOAc. Yield: 56\% (38 mg, $0.13 \mathrm{mmol}$ ). Appearance: violet solid. Mp: $272-274{ }^{\circ} \mathrm{C}$. TLC: $\mathrm{R}_{\mathrm{f}}=0.13$ (Toluene: $i$-PrOH $=3: 1$ ). ${ }^{1} \mathrm{H}$ NMR (DMSO- $\left.d_{6}, 200 \mathrm{MHz}\right): \delta=3.49-3.74(\mathrm{bs}, 4 \mathrm{H}), 6.71(\mathrm{t}, J=8.0 \mathrm{~Hz}, 1 \mathrm{H}), 7.26(\mathrm{q}, J=7.6 \mathrm{~Hz}, 1 \mathrm{H})$, $7.45(\mathrm{~d}, J=8.4 \mathrm{~Hz}, 1 \mathrm{H}), 7.89$ (d, $J=12.5 \mathrm{~Hz}, 1 \mathrm{H}), 8.07(\mathrm{~s}, 1 \mathrm{H}), 8.26(\mathrm{~s}, 1 \mathrm{H}), 9.54(\mathrm{~s}, 1 \mathrm{H}) .{ }^{13} \mathrm{C}$ NMR (DMSO- $\left.d_{6}, 50 \mathrm{MHz}\right): \delta=43.0(\mathrm{t}), 59.5(\mathrm{t}), 105.1\left(\mathrm{~d},{ }^{3} J_{\mathrm{C}-\mathrm{F}}=20.8 \mathrm{~Hz}\right), 107.1\left(\mathrm{~d},{ }^{2} J_{\mathrm{C}-\mathrm{F}}=26.5\right.$ $\mathrm{Hz}), 109.3(\mathrm{~s}), 114.4\left(\mathrm{q},{ }^{6} J_{\mathrm{C}-\mathrm{F}}=2.1 \mathrm{~Hz}\right), 128.3\left(\mathrm{q},{ }^{5} J_{\mathrm{C}-\mathrm{F}}=9.9 \mathrm{~Hz}\right), 137.5(\mathrm{~d}), 142.6\left(\mathrm{~d},{ }^{4} J_{\mathrm{C}-\mathrm{F}}=11.3\right.$ $\mathrm{Hz}), 149.9$ (s), 152.7 (s), 155.2 (s), 162.3 (d, $\left.{ }^{1} J_{\mathrm{C}-\mathrm{F}}=239.5 \mathrm{~Hz}\right)$. HR-MS: Predicted $[\mathrm{MH}]^{+}=$ 289.1208; Measured $[\mathrm{MH}]^{+}=289.1216$. Diff. in $\mathrm{ppm}=2.77$.

2-[2-(3-Bromophenylamino)-9H-purin-6-ylamino]ethanol (15). Compound 5 (42 mg, 0.19 mmol, 1 equiv) and 3-bromoaniline ( $84 \mathrm{mg}, 0.49 \mathrm{mmol}, 2.5$ equiv) were dissolved in $\mathrm{n}-\mathrm{BuOH}$ (2 $\mathrm{mL}$ ) and reacted according to general procedure B. A precipitate was formed and pure product 15 was obtained by filtration and washing with EtOAc. Yield: 52\% (35 mg, $0.10 \mathrm{mmol}$ ). Appearance: colorless solid. Mp: $285-286{ }^{\circ} \mathrm{C}$. TLC: $\mathrm{R}_{\mathrm{f}}=0.19$ (Toluene: $i$-PrOH $=3: 1$ ). ${ }^{1} \mathrm{H}$ NMR (DMSO- $\left.d_{6}, 200 \mathrm{MHz}\right): \delta=3.51-3.79$ (bs, 4H), 7.10-7.32 (m, 2H), $7.62(\mathrm{~d}, J=8.0 \mathrm{~Hz}, 1 \mathrm{H}), 8.16$ $(\mathrm{s}, 1 \mathrm{H}), 8.71(\mathrm{~s}, 1 \mathrm{H}), 8.79(\mathrm{~s}, 1 \mathrm{H}), 9.89(\mathrm{~s}, 1 \mathrm{H}) .{ }^{13} \mathrm{C}$ NMR (DMSO- $\left.d_{6}, 50 \mathrm{MHz}\right): \delta=43.0(\mathrm{t}), 59.4$ (t), 105.8 (s), 117.9 (d), 121.4 (d), 121.5 (s), 124.5 (d), 130.4 (d), 141.5 (s), 148.9 (s), 154.7 (s). HR-MS: Predicted $[\mathrm{MH}]^{+}=349.0407$; Measured $[\mathrm{MH}]^{+}=349.0418$. Diff. in ppm $=3.15$.

2-[2-(4-Fluorophenylamino)-9H-purin-6-ylamino]ethanol (16). Compound 5 (40 mg, 0.18 mmol, 1 equiv.) and 4-fluoroaniline (52 mg, $0.47 \mathrm{mmol}, 2.5$ equiv) were dissolved in $\mathrm{n}-\mathrm{BuOH}$ (2 $\mathrm{mL}$ ) and reacted according to general procedure B. A precipitate was formed and pure product 16 was obtained by filtration and washing with EtOAc. Yield: 89\% (48 mg, $0.17 \mathrm{mmol}$ ). Appearance: violet solid. Mp: 286-288 ${ }^{\circ} \mathrm{C}$. TLC: $\mathrm{R}_{\mathrm{f}}=0.21$ (Toluene: $i$-PrOH $=3: 1$ ). ${ }^{1} \mathrm{H}$ NMR (DMSO- $\left.d_{6}, 200 \mathrm{MHz}\right): \delta=3.48-3.78(\mathrm{bs}, 4 \mathrm{H}), 7.16(\mathrm{t}, J=8.0 \mathrm{~Hz}, 2 \mathrm{H}), 7.66(\mathrm{q}, J=7.6 \mathrm{~Hz}, 2 \mathrm{H})$, 
$8.63(\mathrm{~s}, 1 \mathrm{H}), 8.94(\mathrm{~s}, 1 \mathrm{H}), 9.94(\mathrm{~s}, 1 \mathrm{H}) .{ }^{13} \mathrm{C}$ NMR (DMSO- $\left.d_{6}, 50 \mathrm{MHz}\right): \delta=43.4(\mathrm{t}), 59.2(\mathrm{t})$, $105.7(\mathrm{~s}), 115.2\left(\mathrm{q},{ }^{2} J_{\mathrm{C}-\mathrm{F}}=22.3 \mathrm{~Hz}\right), 121.9\left(\mathrm{q},{ }^{3} J_{\mathrm{C}-\mathrm{F}}=8.2 \mathrm{~Hz}\right), 135.3\left(\mathrm{~d},{ }^{4} J_{\mathrm{C}-\mathrm{F}}=1.4 \mathrm{~Hz}\right), 139.0(\mathrm{~d})$, 148.3 (s), 151.5 (s), 153.5 (s), 157.9 (d, ${ }^{1} J_{\mathrm{C}-\mathrm{F}}=240.9 \mathrm{~Hz}$ ). HR-MS: Predicted $[\mathrm{MH}]^{+}=289.1208$; Measured $[\mathrm{MH}]^{+}=289.1214$. Diff. in $\mathrm{ppm}=2.08$.

3-[(2-Chloro)-9H-purin-6-ylamino]propan-1-ol (17). Compound 1 (100 mg, 0.5 mmol, 1 equiv), propanolamine (75 mg, $0.58 \mathrm{mmol}, 1.1$ equiv) and DIPEA (44 mg, $0.58 \mathrm{mmol}, 1.1 \mathrm{equiv}$ ) were dissolved in $\mathrm{n}-\mathrm{BuOH}(2 \mathrm{~mL})$ and reacted according to general procedure A. A precipitate was formed and crude product $\mathbf{1 7}$ was obtained by filtration and washing with cold $\mathrm{n}-\mathrm{BuOH}$. Yield: 64\% (77 mg, $0.38 \mathrm{mmol}$ ). Appearance: colorless solid. TLC: $\mathrm{R}_{\mathrm{f}}=0.21$ (Toluene: $\mathrm{i}-\mathrm{PrOH}$ $=3: 1)$.

3-[2-(4-Methoxyphenylamino)-9H-purin-6-ylamino]propan-1-ol (18). Compound 17 (77 mg, $0.34 \mathrm{mmol}, 1$ equiv) and 4-methoxyaniline (105 mg, $0.85 \mathrm{mmol}, 2.5$ equiv) were dissolved in $\mathrm{n}$ $\mathrm{BuOH}(3 \mathrm{~mL})$ and reacted according to general procedure $\mathrm{B}$. A precipitate was formed and pure product 18 was obtained by filtration and washing with cold ethanol. Yield: $84 \%$ (89 mg, 0.28 mmol). Appearance: colorless solid. Mp: $232-233{ }^{\circ} \mathrm{C}$. TLC: $\mathrm{R}_{\mathrm{f}}=0.30$ (Toluene: $i$-PrOH $=3: 1$ ). ${ }^{1} \mathrm{H}$ NMR (DMSO- $\left.d_{6}, 200 \mathrm{MHz}\right): \delta=1.78$ (quin, $\left.J=6.6 \mathrm{~Hz}, 2 \mathrm{H}\right), 3.46-3.64(\mathrm{~m}, 4 \mathrm{H}), 3.75(\mathrm{~s}, 3 \mathrm{H})$, $6.93(\mathrm{~d}, J=8.9 \mathrm{~Hz}, 2 \mathrm{H}), 7.53(\mathrm{~d}, J=8.9 \mathrm{~Hz}, 2 \mathrm{H}), 8.45(\mathrm{~s}, 1 \mathrm{H}), 9.05(\mathrm{~s}, 1 \mathrm{H}), 9.73(\mathrm{~s}, 1 \mathrm{H}) .{ }^{13} \mathrm{C}$ NMR (DMSO- $\left.d_{6}, 50 \mathrm{MHz}\right): \delta=31.6(\mathrm{t}), 38.0(\mathrm{t}), 54.2(\mathrm{q}), 58.1(\mathrm{t}), 113.9(\mathrm{~d}), 122.4(\mathrm{~d}), 131.3$ (s), $139.4(\mathrm{~d}), 147.4$ (s), 150.8 (s), 155.3 (s). HR-MS: Predicted $[\mathrm{MH}]^{+}=315.1569$; Measured $[\mathrm{MH}]^{+}=315.1588$. Diff. in ppm $=6.0$.

3-[2-(4-Morpholinophenylamino)-9H-purin-6-ylamino]propan-1-ol (19). Compound 17 (67 $\mathrm{mg}, 0.29 \mathrm{mmol}, 1$ equiv) and 4-morpholinoaniline (129 $\mathrm{mg}, 0.73 \mathrm{mmol}, 2.5$ equiv) were dissolved in $\mathrm{n}-\mathrm{BuOH}(2 \mathrm{~mL})$ and reacted according to general procedure $\mathrm{B}$. A precipitate was formed and pure product 19 was obtained by filtration and washing with cold ethanol. Yield: 77\% (84 mg, $0.23 \mathrm{mmol}$ ). Appearance: beige solid. Mp: $221-224{ }^{\circ} \mathrm{C}$. TLC: $\mathrm{R}_{\mathrm{f}}=0.51$ (Toluene: $i$ $\mathrm{PrOH}=3: 1)^{1} \mathrm{H}$ NMR (DMSO- $d_{6}, 200 \mathrm{MHz}$ ): $\delta=1.69-1.88$ (quin, $J=6.4 \mathrm{~Hz}, 2 \mathrm{H}$ ), 2.95-3.52 (bs, 4H), 3.47- 3.67 (m, 4H), 3.71-3.98 (bs, 4H), 7.23 (d, $J=8.6 \mathrm{~Hz}, 2 \mathrm{H}), 7.63$ (d, $J=8.4 \mathrm{~Hz}, 2 \mathrm{H})$, $8.56(\mathrm{~s}, 1 \mathrm{H}), 9.15(\mathrm{~s}, 1 \mathrm{H}), 9.91(\mathrm{~s}, 1 \mathrm{H}) .{ }^{13} \mathrm{C} \mathrm{NMR}\left(\mathrm{DMSO}-d_{6}, 50 \mathrm{MHz}\right): \delta=31.6(\mathrm{t}), 45.3(\mathrm{t}), 50.6$ $(\mathrm{t}), 58.1(\mathrm{t}), 65.1$ (t), 117.7 (d), 120.9 (d), 139.0 (d), 147.8 (s), 151.4 (s). HR-MS: Predicted $[\mathrm{MH}]^{+}=369.1991$; Measured $[\mathrm{MH}]^{+}=369.1998$. Diff. in ppm $=1.80$.

\section{Biological test methods}

Cell type. C2C12 skeletal myoblasts (American Type Culture Collection, ATCC).

Cell culture. $\mathrm{C} 2 \mathrm{C} 12$ cells were propagated in growth medium consisting of Dulbecco's modified Eagle's medium (DMEM) containing $4.5 \mathrm{~g} / 1$ glucose, $4 \mathrm{mM}$ L-glutamine, $50 \mathrm{U} / \mathrm{ml}$ penicillin, $50 \mathrm{~g} / \mathrm{ml}$ streptomycin, and $20 \%$ fetal calf serum. The cells were incubated at $37{ }^{\circ} \mathrm{C}$ and $5 \% \mathrm{CO}_{2}$, and when about $50-70 \%$ confluence was reached, in undifferentiated skeletal muscle cells (myoblasts), differentiation was induced by serum reduction. For this purpose, myoblasts were incubated in differentiation medium that was identical to the growth medium, except that it contained $2 \%$ horse serum instead of $20 \%$ fetal calf serum. Small molecules to be 
tested were always added at the same time as differentiation was induced. DMSO, which was used as solvent for the small molecules, was added in equal amounts to "control cells". The media were changed three times per week.

\section{Assessment of cardiomyogenic activity of the small molecules}

To test if small molecules induce cardiomyogenic function in $\mathrm{C} 2 \mathrm{C} 12$ cells their effects on the electrophysiological properties of the cells were tested using the whole cell patch clamp technique. Therefore, cells were treated for 4 days with small molecules in a final concentration of 2 or $20 \mathrm{nM}$. Ionic currents in untreated and small molecule-treated cells were then compared. $\mathrm{Na}$-currents were recorded at room temperature $\left(22 \pm 1.5^{\circ} \mathrm{C}\right)$ with an Axoclamp 200B patchclamp amplifier. Pipettes were formed from aluminosilicate glass (AF150-100-10; Science Products) with a P-97 horizontal puller (Sutter Instruments) and have resistances between 1 and 2 mega ohms when filled with the recording pipette solution $(105 \mathrm{mM} \mathrm{CsF}, 10 \mathrm{mM} \mathrm{NaCl}, 10$ mM EGTA, and $10 \mathrm{mM}$ HEPES, pH 7.3). Voltage-clamp protocols and data acquisition were performed with pCLAMP 6.0 software (Axon Instruments) via a 12-bit A/D-D/A interface (Digidata 1200; Axon Instruments). A bathing solution consisting of $140 \mathrm{mM} \mathrm{NaCl}, 2.5 \mathrm{mM}$ $\mathrm{KCl}, 1 \mathrm{mM} \mathrm{CaCl}_{2}, 1 \mathrm{mM} \mathrm{MgCl}_{2}$, and $10 \mathrm{mM}$ HEPES, pH 7.4, was used to obtain recordings.

\section{Acknowledgements}

We gratefully acknowledge financial support to this project via AWS (Uni:Invent Project Z090391). M.K. would like to thank One-World-Scholarship Program for providing a PhD fellowship.

\section{References}

1. Collingwood, S. P.; Hayler, J.; Le Grand, D. M.; Mattes, H.; Menearr, K. A.; Walker, C. V.; Cockcroft, X. L. WO01/09134, 2001.

2. Hurst, D. T. The Chemistry and Biology of Pyrimidines, Purines and Pteridines; Wiley: Chichester, U.K., 1980.

3. Kelley, J. L.; Linn, J. A.; Krochamal, M.P.; Selway, J. W. T. J. Med. Chem. 1988, 31, 2001.

4. (a) Garcia-Echeverria, C.; Taxler, P.; Evans, D. B.; Med. Res. Rev 2000, 20, 28 and references therein. (b) Schindler, T.; Bormann, W.; Pellicena, P.; Miller, W. T.; Claerkson, B.; Kuryan, J. Science 2000, 289, 1938 and references therein.

5. Fiorini, M. T.; Abell, C. Tetrahedron Lett. 1998, 39, 1827.

6. (a) Gray, N. S.; Kwon, S.; Schultz, P. G, Tetrahedron Lett. 1997, 38, 1161. (b) Norman, T. C.; Gray, N. S.; Koh, J. T.; Schultz, P. G. J. Am. Chem. Soc. 1996, 118, 7430. (c) Nugiel, D. A.; Cornelius, L. A. M.; Corbett, J. W. J. Org. Chem. 1997, 62, 201. 
7. (a) Chen, S.; Zhang, Q.; Wu, X.; Schultz, P. G.; Ding, S. J. Am. Chem. Soc. 2004, 126, 410.

(b) Chen, S.; Ding, S.; Schultz, P. G. PCT Int. Appl. 2005, WO, 2005047524 A2 20050526. CAN 142:478415.

8. (a) Davis, R. L.; Weintraub, H.; Lasser, A. B.; Cell 1987, 51, 987. (b) Kulessa, H.; Frampton, J.; Graf, T. Genes Dev. 1995, 9, 1250.

9. (a) Gurdon, J. B.; Byrne, J. A. Proc. Natl. Acad. Sci. USA 2003, 100, 8048. (b) Wilmut, I.; Schnieke, A. E.; McWhir, J.; Kind, A. J.; Campbell, K. H. Nature 1997, 385, 810. (c) Gurdon, J. B.; Melton, D. A. Science 2008, 322, 1811. (d) Hochedlinger, K.; Jaenisch, R. Nature 2002, 415, 1035.

10. (a) Takahashi, K.; Yamanaka, S. Cell 2006, 126, 663. (b) Maherali, N.; Hochedlinger, K. Cell Stem Cell 2008, 3, 595. (c) Lowry, W. E.; Richter, L.; Yachechko, R.; Pyle, A. D.; Tchieu, J.; Sridharan, R.; Clark, A. T.; Plath, K. Proc. Natl. Acad. Sci. USA 2008, 105, 2883. (d) Park, I. H.; Zhao, R.; West, J. A.; Yabuuchi, A.; Huo, H.; Ince, T. A.; Lerou, P. H.; Lensch, M. W.; Daley, G. Q. Nature 2008, 451, 141. (e) Takahashi, K.; Tanabe, K.; Ohnuki, M.; Narita, M.; Ichisaka, T.; Tomoda, K.; Yamanaka, S. Cell 2007, 131, 861. (f) Yu, J., Vodyanik, M. A., Smuga-Otto, K., Antosiewicz-Bourget, J., Frane, J. L., Tian, S.; Nie, J.; Jonsdottir, G. A.; Ruotti, V.; Stewart, R.; Slukvin, I. I.; Thomson, J. A. Science 2007, 318, 1917.

11. Feng, B.; Jiang, J.; Kraus, P.; Ng, J. H.; Heng, J. C.; Chan, Y. S.; Yaw, L. P.; Zhang, W.; Loh, Y. H.; Han, J.; Vega, V. B.; Cacheux-Rataboul, V.; Lim, B.; Lufkin, T.; Ng, H.-H. Nat. Cell Biol. 2009, 11, 197.

12. (a) Feng, B.; Ng, J. H.; Heng, J. C.; Ng, H. H. Cell Stem Cell 2009, 4, 301. (b) Chen, J. K.; Firestone, A. J. Morgan, T. C.; Lee, M.-H.; Kimble, J. Nat. Chem. Biol. 2010, 6, 102. (c) Kim, N. R.; Kang, S. K.; Ahn, H. H.; Kwon, S. W.; Park, W. S.; Kim, K. S.; Kim, S. S.; Jung, H. J.; Choi, S. U.; Ahn, J. H.; Kim, K. R. J. Med. Chem 2009, 52, 7931. (d) De Medina, P.; Paillasse, M. R.; Payre, B.; Silvente-Poirot, S.; Poirot, M. J. Med. Chem. 2009, 52, 7765. (e) Firestone, A. J.; Chen, J. K. ACS Chem. Biol. 2010, 5, 15.

13. Williams, D. R.; Lee, M. R; Song, Y. A; Ko, S. K.; Kim, G. H.; Shin, I. J. Am. Chem. Soc. 2007, 129, 9258.

14. Warashina M.; Min, K. H.; Kuwabara, T.; Huynh, A.; Gage, F. H.; Schultz, P. G.; Ding, S. Angew. Chem. Int. Ed. 2006, 45, 591.

15. (a) Wu, X.; Ding, S.; Ding, Q.; Gray, N. S.; Schultz, P. G. J. Am. Chem. Soc. 2004, 126, 1590. (b) Wu, X.; Ding, S.; Schultz, P. G. PCT Int. Appl. 2005, WO 2005068437; CAN 143:172888. (c) Willems, E.; Bushway, P. J.; Mercola, M. Pediatr. Cardiol. 2009, 30, 635.

16. Sadek, H.; Hannack, B.; Choe, E.; Wang, J.; Latif, S.; Garry, M. G.; Garry, D. J.; Longgood, J.; Frantz, D. E.; Olson, E. N.; Hsieh, J.; Schneider, J. W. Proc. Natl. Acad. Sci. USA 2008, $105,6063$.

17. (a) Urbanek, K.; Rota, M.; Cascapera, S.; Bearzi, C.; Nascimbene, A.; De Angelis, A.; Hosoda, T.; Chimenti, S.; Baker, M.; Limana, F.; Nurzynska, D.; Torella, D.; Rotatori, F.; Rastaldo, R.; Musso, E.; Quaini, F.; Leri, A.; Kajstura, J.; Anversa, P. Circ Res. 2005, 97, 
663. (b) Nagai, T.; Shiojima, I.; Matsuura, K.; Komuro, I. Circ. Res. 2005, 97, 615. (c) Barile, L.; Chimenti, I.; Gaetani, R.; Forte, E.; Miraldi, F.; Frati, G.; Messina, E.; Giacomello, A. Nat Clin Pract Cardiovasc Med. 2007, 4 (Suppl 1), S9-S14

18. Eicher, T.; Hauptmann, S. In The Chemistry of Heterocycles; Wiley-VCH: Weinheim, 2003; p $269 \mathrm{ff}$.

19. Zeng, Q.; Huang, B.; Danielsen, K.; Shukla, R.; Nagy, T. Org. Process Res. Dev. 2004, 8, 962.

20. Altmann, E.; Cowan-Jacob, S. W.; Missbach, M. J. Med. Chem. 2004, 47, 5833.

21. Ciszewski, L.; Waykole, L.; Prashad, M.; Repic, O. Org. Process Res. Dev. 2006, 10, 799.

22. Chen, S.; Takanashi, S.; Zhang, Q.; Xiong, W.; Zhu, S.; Peters, E. C.; Ding, S.; Schultz, P. G. Proc. Natl. Acad. Sci. USA 2007, 104, 10482. 